๑ Ю. Ю. Віцюк, к.т.н., Т. А. Роїк, Д.т.н., професор,

П. О. Киричок, д.Т.н., професор, А. П. Гавриш, д.Т.н., професор, НТУУ «КПІ», Київ, Україна

\title{
АНАЛІЗ ТЕМПЕРАТУРНОГО ПОЛЯ ПРИ ДИНАМІЧНОМУ УДАРІ АБРАЗИВНОГО ЗЕРНА В ПРОЦЕСІ ШЛІФУВАННЯ КОМПОЗИТНИХ ДЕТАЛЕЙ ТЕРТЯ ДРУКАРСЬКИХ МАШИН
}

\author{
В статті наведені результати теоретичних досліджень \\ динамічного зміцнення та параметрів наклепу у тонких \\ поверхневих шарах композитних деталей тертя для \\ друкарських машин, виготовлених з нових зносостійких \\ композитних матеріалів на основі відходів інструментальних \\ сталей та оброблених методом тонкого абразивного \\ шліфування.
}

\begin{abstract}
Ключові слова: композитні деталі, удар, динамічне зміцнення, температурне поле, наклеп, абразивне шліфування.
\end{abstract}

\section{Постановка проблеми}

Розвиток сучасної високопродуктивної техніки вимагає забезпечення високих параметрів надійності, працездатності та зносостійкості друкарських машин, їх вузлів і деталей тертя у широкому спектрі умов експлуатації від нормальних до експериментальних (швидкості обертання до 800 об./хв., тиск 3-8 МПа). Одним із поширених видів деталей тертя, що експлуатуються у зазначених умовах, $€$ підшипники ковзання високошвидкісних машин поліграфічної техніки, зокрема, ротаційних апаратів типу KBA «Rapid-105», деталей вузлів тертя газоперекачуючих станцій, компресорів магістральних газогонів та інше.

Створення нових композиційних підшипникових матеріалів для важких умов експлуатації [1-5] з широким вико- ристанням як основи для них утилізованих та регенерованих шліфувальних входів алюмінієвих, штампових та інструментальних сталей переконливо довело наявність стабільно високих триботехнічних властивостей цих композитів [6].

Відомості про технологічні засади виготовлення та прецизійної механічної обробки нових композитних підшипників детально наведені у роботах [5-8]. Цими дослідженнями було доведено, що на строки служби підшипників ковзання 3 нових композитів впливають показники якості поверхонь оброблення, а саме, параметри шорсткості поверхонь Ra та властивості поверхневого шару, 3 якого абразивним інструментом здійснюється зрізання тонких стружок. 3 цієї точки зору висувались задачі досягнення

(c) $2014 \mathrm{p}$. 
характеристик мінімальної шорсткості Ra поверхонь оброблення, яка $\epsilon$ передумовою високих функціональних властивостей підшипників. 3 цією метою були створені технологічні процеси, де фінішна абразивна обробка здійснювалась із застосуванням методів тонкого абразивного та алмазного шліфування, а також методів магнітно-абразивного оброблення [7-9].

Високі техніко-економічні показники застосування у промисловості найсучасніших шліфувальних інструментів з синтетичних надтвердих матеріалів (алмаз синтетичний, кубоніт, ельбор, боразон [11, 12]) обумовили необхідність всебічного дослідження питань забезпечення вимог якості поверхонь деталей тертя друкарських машин 3 метою безперервного зростання їх параметрів надійності і, в першу чергу, таких показників як коефіцієнт готовності машин, довговічність, напрацювання на одне руйнування, ремонтоздатність. Зазначимо, що саме нові композиційні матеріали деталей тертя для друкарської техніки, які створені для суттєвого підвищення параметрів зносостійкості, є складно легованими сплавами [1-3]. Вони містять у своєму складі такі елементи, як вольфрам, ванадій, титан, кобальт, ніобій, нікель та цирконій. Що свідчить про їх важко оброблюваність методами механічного оброблення.

В останні роки були проведені всебічні дослідження надтонких процесів алмазно-абразивного оброблення деталей тертя, що виготовлені з новітніх композит- них сплавів [1-4] і, які мали на меті отримання науково обґрунтованих рекомендацій для промисловості з вибору типів інструментів та режимів різання, що забезпечують необхідні параметри шорсткості поверхонь деталей [5-10, 12-16].

На жаль усі ці дослідження виконувались $з$ урахуванням дії комплексу факторів у статиці і не враховували специфіки дії динаміки процесу різання матеріалів. Адже відомо, що, наприклад, технологічний процес шліфування відбувається зі швидкостями обертання кругу 20-50 м/с, ці значення швидкостей на порядок перевищують швидкості динамічних випробовувань на міцність $(\approx 1,0-$ 1,5 м/с) металевих матеріалів [11]. Це суттєво впливає на розуміння фізичної сутності складних явищ, які відбуваються у поверхневих шарах деталей і які формують, кінець кінцем, фінішні значення параметрів поверхонь деталей пар тертя.

Зазначимо, що при динамічному навантаженні, яким $€$ процеси тонкого шліфування, процес зрізання тонких стружок відбувається зі значним збільшенням дії силового та температурного полів [7, 8, 15, 16], зростанням пластичного деформування [6] в першу чергу, внаслідок ускладнення оброблюваності високолегованих композитних матеріалів, до складу лігатур яких входять вольфрам, ванадій, молібден, цезій, нікель, цирконій [1-4] i різкого збільшення тертя ріжучих зерен шліфувального кругу, що наносять динамічні удари 3 великими швидкостями по 


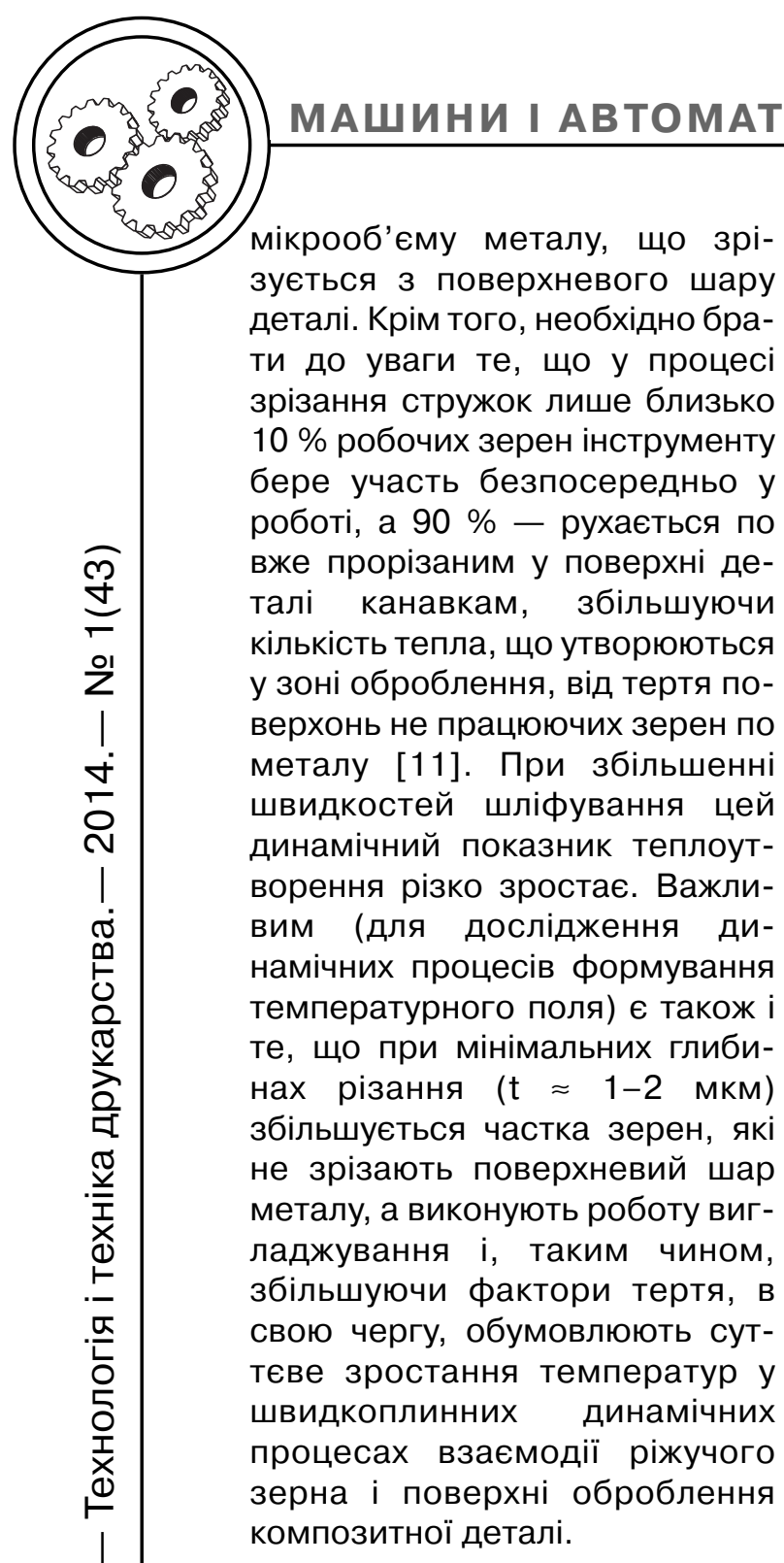

Мета роботи

Метою даної роботи було виконання теоретичних досліджень утворення у зоні зрізання стружки поодиноким шліфуванням зерном температурного поля, що утворюється на ріжучому лезі абразивного зерна при його динамічному ударі по поверхні композитної деталі тертя друкарських машин, які виготовлені для умов експлуатації в екстремальних умовах навантаження 3 новітніх високолегованих зно- состійких композиційних сплавів [1-4], синтезованих шламових відходів інструментального виробництва з домішками твердого мастила $\mathrm{CaF}_{2}$.

\section{Результати проведених досліджень}

Підвищення температури поверхневого шару оброблюваної поверхні деталі при шліфуванні відбувається за рахунок дії сили тертя ковзання шліфувального зерна [11]. Джерело теплоти довжиною $\mathrm{L}_{2}$, переміщується, для достатньо широких діапазонів варіювання технологічними режимами і відноситься до швидкоплинних теплових джерел, для яких критерій Пекле становить $\mathrm{Pe}>10$, визначеного залежністю [17]:

$$
\mathrm{Pe}=\left(\mathrm{SL}_{2}\right) / \mathrm{f} \text {, }
$$

де $\mathrm{Pe}$ - критерій Пекле; S швидкість переміщення поверхні оброблення (подача) в зоні контактування зерен 3 поверхнею оброблення; а - коефіцієнт температуропровідності.

Подальше дослідження теплового впливу ґрунтується на умові незмінності коефіцієнту тертя ковзання $f$ всією довжиною контакту $L_{2}$ з поверхнею оброблення, а розподілення інтенсивності теплового потоку $\Phi_{\text {ті }}$ відповідає розподіленню сил тертя ковзання у межах контакту $\mathrm{L}_{2}$. Крім того, враховувались зміни теплового впливу на поверхню, викликані зміною напряму взаємного переміщення (попутне чи зустрічне переміщення поверхні відносно напряму обертання кругу), коли функції розподілення теплового 
потоку є симетричними відносно прямої $x=L_{2}$ (рис. 1).

Застосовуючи отриману у роботі [3] залежність

$P_{n}=k_{0}\left[\left(1-\frac{L_{1}}{L_{2}}\right)-\left(1-\frac{L_{1}}{L_{2}}\right)^{5}\right] P_{n_{\max }}$,

$\left(\mathrm{P}_{\mathrm{n}_{\max }}\right.$ - максимальне значення нормальної складової результуючого зусилля; $\left.\mathrm{k}_{0}=1,869186\right)$, підставимо функції розподілення сил тертя всією зоною контактування:

- попутнє шліфування

$$
\begin{aligned}
& \sigma_{\mathrm{X}_{1}}=\left(\mathrm{L}_{1}\right)= \\
& =\mathrm{k}_{0} \sigma_{\mathrm{x}_{0}}\left[\left(1-\frac{\mathrm{L}_{1}}{\mathrm{~L}_{2}}\right)-\left(1-\frac{\mathrm{L}_{1}}{\mathrm{~L}_{2}}\right)^{5}\right]
\end{aligned}
$$

- зустрічне шліфування

$$
\begin{aligned}
& \sigma_{\mathrm{x}_{1}}=\left(\mathrm{L}_{1}\right)= \\
& =\mathrm{k}_{0} \sigma_{\mathrm{x}_{0}}\left[\left(1-\frac{\mathrm{L}_{1}}{\mathrm{~L}_{2}}\right)-\left(1-\frac{\mathrm{L}_{1}}{\mathrm{~L}_{2}}\right)^{5}\right]
\end{aligned}
$$

де $\sigma_{\mathrm{x}_{1(2)}}-$ питома сила тертя (дія сили на одиницю площі контакту між робочими зернами та поверхнею обробки); $\sigma_{x_{0}}-$ найближче питоме зусилля.

Загальна сила тертя $\mathrm{F}_{\mathrm{TP}}$ на площині контактування (B.L2) визначається наступною залежністю

$$
\begin{aligned}
& F_{T P}=A L_{2} k_{0} \sigma_{X_{0}} \int_{0}^{b_{2}}\left[\frac{L_{1}}{L_{2}}-\left(\frac{L_{1}}{L_{2}}\right)^{5}\right] d L_{1}= \\
& =\frac{1}{3} A L_{2} k_{0} \sigma_{X_{0}} .
\end{aligned}
$$

Встановлення джерела теплоутворення для рішення задачі поширення температурного поля та аналітичне визначення ве- личини температури нагрівання тіла в умовно прийнятій точці А $(\mathrm{x}, \mathrm{y})$, що розташована на глибині залягання Y (рис. 1) детально досліджені авторами даної роботи $[11,16]$.

Результатом проведених теоретичних досліджень слугує узагальнений вираз встановлення температури нагрівання поверхневого шару металу від всіх наявних теплових джерел прийнятим плоским джерелом:

$\mathrm{T}(\mathrm{X}, \mathrm{Y})=\frac{1}{\mathrm{v}}[\mathrm{a} /(\pi \mathrm{S})]^{0,5}$.

$\cdot \sum_{n=-\infty}^{n=+\infty} \int_{0}^{j} \frac{\Phi_{T_{1(2)}}\left(L_{1}\right)}{\left(X-L_{1}\right)^{0,5}} \cdot \exp \left[-\frac{S(Y-2 n Z)^{2}}{4 a\left(X-L_{1}\right)}\right] d\left(L_{1}\right)$.

Врахування напряму переміщення прийнятого джерела (зустрічне і попутнє шліфування) дозволило отримати розрахункові залежності для встановлення значення поширеної в матеріалі теплоти $[18,19]$

$$
\begin{aligned}
& \mathrm{T}_{1_{\max }}=\frac{4,781084}{v(\pi \mathrm{S})^{0,5}} \cdot \frac{\mathrm{P}_{\mathrm{k}}\left(\mathrm{V}_{\mathrm{u}}-\mathrm{S}\right)}{\mathrm{BL}_{2}^{0,5}} ; \\
& \mathrm{T}_{2_{\max }}=\frac{4,318308}{v(\pi \mathrm{S})^{0,5}} \cdot \frac{\mathrm{P}_{\mathrm{z}}\left(\mathrm{V}_{\mathrm{u}}+\mathrm{S}\right)}{\mathrm{BL}_{2}^{0,5}} ;
\end{aligned}
$$

Результатом проведення ряду експериментальних досліджень і замірів теплового поля у процесі динамічного механічного контактування зерна 3 поверхнею оброблення композитного зразка 7ХГ2ВМФ+ $+5 \% \mathrm{CaF}_{2}$ на глибині, наприклад, $Y=3 \cdot 10^{-4}$ м температура нагрівання становила $\mathrm{T}_{2}$ exp $=$ $=101^{\circ} \mathrm{C}[16]$.

Особливості процесу тонкого шліфування, що розглядається, полягає, як вказується вище, у послідовному суміщенні теплового і динамічного впливів 


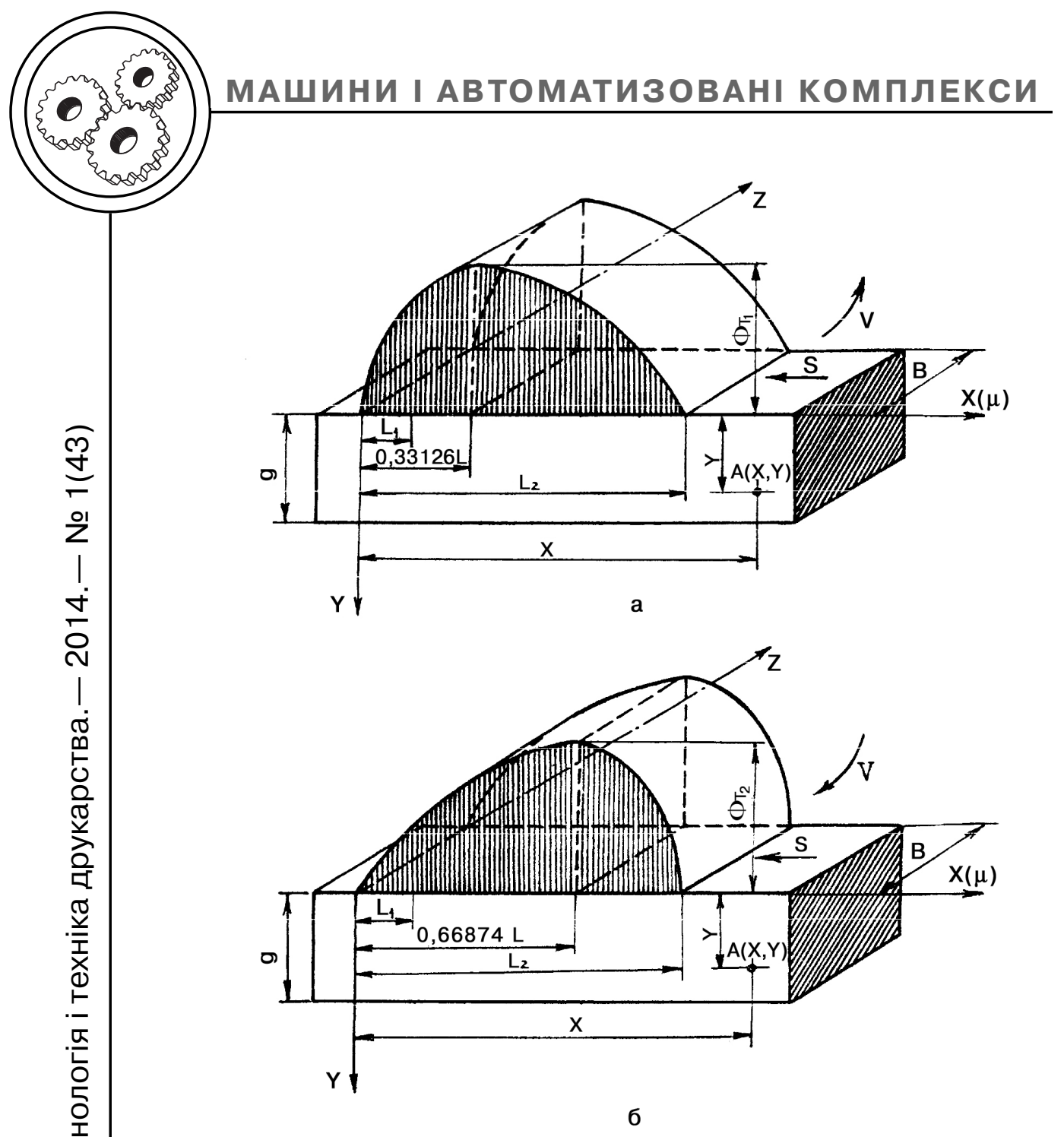

Рис. 1. Розподілення площиною контактування інтенсивності теплового потоку, викликаного ковзанням шліфувального зерна ріжучою поверхнею при попутній (а) та зустрічній (б) обробках

на поверхню оброблення. В свою чергу динамічне контактування, з точки зору специфічних особливостей процесу, слід виділити в окремі підгрупи, що характеризують взаємодію окремих зерен з поверхнею обробки: силовий вплив зерна [15], динамічний, тиск викликаний потужними властивостями зв'язки кругу та удару, сформованого дією зерна кругу, ди- намічна взаємодія жорсткого шліфувального зерна.

Тиск, що впливає на поверхню металу, викликаний дією особливостей зв'язки та тертя зерен по поверхні композиту.

Згідно досліджень, проведених рядом вчених $[11,20,21]$ динамічний тиск контакту становитиме $\mathrm{P}_{\mathrm{e} / б}=1,15 \cdot 10^{-8}$ Па, величина якого фактично суттєво не впливатиме на фізи- 
ко-механічні зміни у поверхневих шарах металу, і тому в наступних дослідженнях впливом даної зовнішньої сили нехтуємо.

Таким чином, превалюючими впливовими силовими факторами дії на поверхню абразивного оброблення композитних деталей є динамічна взаємодія ріжучих зерен інструменту, яке здійснюється внаслідок лише механічного контактування робочих зерен інструменту і займає провідне місце якісного формування поверхні основного металу виробу.

3 метою узагальнення явищ контактної взаємодії з поверхнею, встановлено ряд спільних закономірностей, що дозволило в наступному розглядати їх як робочий елемент, здатний у процесі динамічної взаємодії сприяти виникненню у поверхневих шарах металу пружнопластичних деформацій [22].

Процес динамічної контактної взаємодії робочих абразивних зерен шліфувального інструменту з композитною поверхнею оброблення деталі та виникаючі внаслідок цього пружно-пластичні деформації у поверхневому шарі матеріалу, отримані авторами даної роботи, співпадають з результатами раніше опублікованих праць [23-26], що були результатами досліджень простих вуглецевих сталей, наприклад, сталі 45. Це додатково свідчить про об'єктивність та коректність отриманих висновків та положень.

Для подальшого сприйняття викладеного матеріалу доцільно навести окремі прийняті визначення та акцентувати увагу на деяких результатах проведених досліджень.

Узагальнене прийняття для попередніх досліджень контактуючого ріжучого зерна та встановлені геометричні параметри (зокрема, радіуса $\mathrm{R}_{11}$ та $\mathrm{R}_{21}$ ) наведені на рис. 2. Зазначимо, що в загальному вигляді (включно 3 елементами динамічного удару) процес деформування композитної поверхні досить реально відображено на рис. 2, де наведена схема дії сили при навантаженнях кожного поодинокого шліфувального зерна у елементі робочого кругу (рис. 2, а) та ударного деформування поверхні, наприклад, кулькою (рис. 2, б).

Встановлено, що доударна кінетична енергія індентора витрачається на пружно-пластичну деформацію поверхні обробки та на пружне деформування контактуючого робочого елементу. Згідно такого твердження, для встановлення величини максимальної контактної сили доцільно застосувати метод простих інтеграцій, представляючи вираз трансцендентно.

$$
\begin{aligned}
& 0,5 m V_{n \delta}^{2}-0,5 \lambda_{i}^{4} \cdot\left(P_{N_{\max }}^{2}-N_{S}^{2}\right)=X \\
& P_{N_{\max }}=\frac{X-0,5 \lambda_{i}^{4} \cdot C_{1}\left(P_{N_{\max }}-N_{S}\right)}{0,5 k_{1} P_{N_{\max }^{1 / 3}}^{1 / 3} \cdot\left(C_{1}+0,8\right)} .
\end{aligned}
$$

Контактне деформування пружно-пластичної поверхні одиничним зерном супроводжується утворенням залишкових пластичних відбитків, форми яких у загальному випадку являють собою еліпси. Геометричні параметри залишкових лунок дозволяють встановлювати окремі характерні особли- 


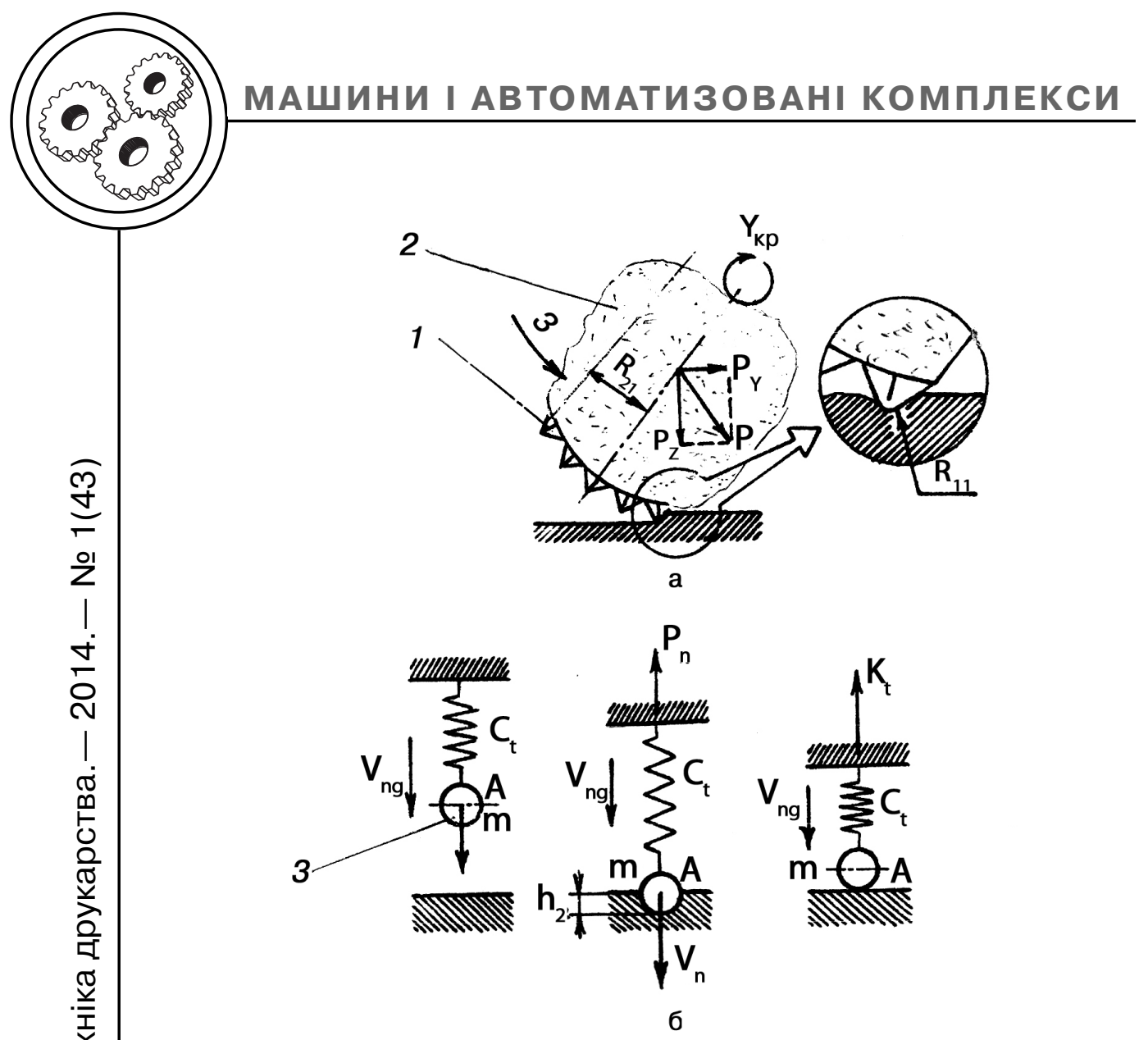

Рис. 2. Схема контактної динамічної взаємодії ріжучого шліфувального зерна з елементом композитної поверхні деталі: 1 - ріжуче зерно інструменту; 2 - елемент шліфувального кругу; 3 - сталева кулька при динамічному навантаженні; $\mathrm{V}_{\text {кр }}$ - швидкість шліфувального кругу; $\mathrm{V}_{\mathrm{ng}}$ - швидкість падіння кульки при динамічному навантаженні; $\mathrm{R}_{11}$ радіус при вершині шліфувального зерна; $\mathrm{R}_{12}$ - радіус поодинокого зерна; $\mathrm{h}_{2}$ - глибина занурення кульки; А - діаметр кульки;

$$
\mathrm{m} \text { - маса кульки }
$$

вості поверхневого деформування та формозмінення шару основного матеріалу виробу внаслідок динамічного контактування різними за формою зернами.

Розміри півосей залишкового на поверхні відбитку (еліпсу) встановлення згідно наступних залежностей:

$$
\left.\begin{array}{l}
\mathrm{a}_{1}=\left[\left(\mathrm{h}_{2_{\text {max }}}+\mathrm{h}_{\mathrm{ië}}\right) \cdot 0,5 \mathrm{~A}^{-1}-\mathrm{h}_{\mathrm{ie}}^{2}\right]^{0,5} ; \\
\mathrm{b}_{1}=\left[\left(\mathrm{h}_{2_{\text {max }}}+\mathrm{h}_{\mathrm{ië}}\right) \cdot 0,5 \mathrm{~B}^{-1}-\mathrm{h}_{\mathrm{ie}}^{2}\right]^{0,5},
\end{array}\right\}
$$

де A і B - геометричні параметри робочої контактної поверхні одиничного індентора, значення яких визначаються залежно від його виду (рис. 2)

$$
\left.\begin{array}{l}
A=0,5 R_{11} ; \\
B=0,5 R_{21}
\end{array}\right\} .
$$

Аналітичне визначення величини $\mathrm{P}_{\mathrm{N}_{\max }}$ шляхом апроксимування функції параболічного виду $\mathrm{B}$ інтервалі $\mathrm{P}_{\mathrm{N}_{\max }}=$ $=\left(10^{2} \ldots 5,5 \cdot 10^{3}\right)$ вказало, що 
відносна середньоквадратична похибка становить 9,6 \%.

Наведені теоретичні дослідження та узагальнення слугують підґрунтям для аналітичного встановлення реального принципового впливу локального рухомого температурного джерела процесу оброблення та контактної взаємодії інструменту 3 поверхнею і розробки математичної моделі механізму усього процесу обробки та якісного формування поверхневого шару основного металу.

Особливості контактування взаємодії робочих зерен інструменту з поверхнею, шлях їх переміщення та період взаємодії дозволяє реально передбачувати температуру нагрівання металу та її поширення у матеріалі у вигляді теплових потоків, викликаних як впливом дією пластичного деформування, так і внаслідок лише механічного контакту. В свою чергу, чітко встановлений механізм температурного поширення дозволяє реально оцінювати процес змін у мікроструктурі поверхневого шару оброблення і заздалегідь, враховуючи специфіку процесу, встановлювати технологічні процеси оброблення.

\section{Висновки}

Узагальнюючи результати наведених теоретичних досліджень та їх порівняння 3 вже виконаними раніше [16] результатами експериментів, доцільно зробити такі основні висновки:
1. Розроблена методика дозволяє з високою ймовірністю прогнозувати очікувані температурні параметри поля у зоні динамічного оброблення поверхонь композитних деталей тертя шліфувальними зернами широкого кола інструментів для усього спектра створених зносостійких матеріалів.

2. Згідно 3 теоретичними розрахунками створена можливість ще до початку обробки деталей (враховуючи деякі режимні параметри технологічного процесу тонкого шліфування поверхонь деталей тертя, наприклад, швидкості кругу, глибини різання) передбачити показники якості поверхонь оброблення з комплексною динамічною дією температурних факторів пластичного деформування та силової дії складових сил різання тонких поверхневих шарів деталей.

3. 3 практичної точки зору наведені аналітичні залежності та розробки дозволяють здійснити попереднє прогнозування якісних характеристик поверхневого шару основного матеріалу оброблювальної деталі відповідно до умов експлуатації пари тертя друкарської машини.

4. У подальшому є доцільним дослідження температурного поля з врахуванням коефіцієнтів тертя по новим композитам різних абразивних матеріалів карбіду кремнію зеленого, монокорунду, електрокорунду білого, алмазу синтетичного, кубоніту та ельбору. 


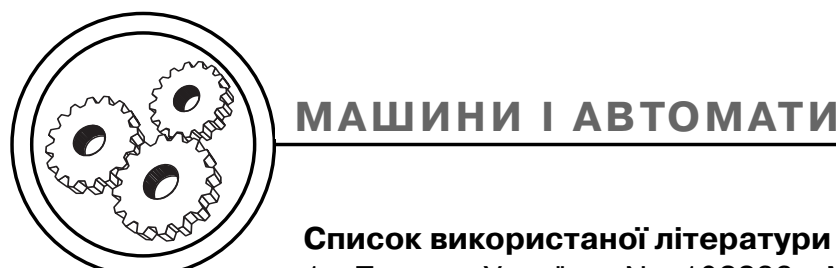

1. Патент України № 102299, МПК С22С33/02. Антифрикційний композиційний матеріал на основі інструментальної сталі / Роїк Т. А., Гавриш А. П., Киричок П. О., Гавриш О. А., Віцюк Ю. Ю., Мельник О. О., опубл. 25.06.2013, Бюл. № 13.

2. Патент України № 41532, МПК С22С33/02. Підшипниковий композиційний матеріал / Роїк Т. А., Гавриш А. П., Гавриш О. А., Віцюк Ю. Ю., Холявко В. В., Мельник О. О., опубл. 25.05.2009, Бюл. № 10.

3. Патент України № 31545, МПК С22С33/02. Антифрикційний композиційний матеріал на основі нікелю / Роїк Т. А., Гавриш А. П., Гавриш О. А., Холявко В. В., Віцюк Ю. Ю., опубл. 10.04.2008, Бюл. № 7.

4. Роїк Т. А. Композиційні підшипникові матеріали для підвищення умов експлуатації / Т. А. Роїк, П. О. Киричок, А. П. Гавриш : Монографія. - К. : НТУУ «КПI», 2007. - 404 c.

5. Роїк Т. А. Сучасні системи технологій заготівельного виробництва в машинобудуванні / Т. А. Роїк, А. П. Гавриш, О. А. Гавриш : Монографія. - К. : EKMO, 2010. - 212 c.

6. Гавриш А. П. Нові технології фінішного оброблення композиційних матеріалів з відходів швидкорізальних сталей на основі аналізу плівок тертя / А. П. Гавриш, Т. А. Роїк, П. О. Киричок, Ю. Ю. Віцюк, О. І. Хмілярчук, О. О. Мельник // Наукові вісті НТУУ «КПІ». - 2011. - № 2. - С. 100-107.

7. Гавриш А. П. Нові технології фінішного оброблення композиційних підшипників ковзання для жорстких умов експлуатації / А. П. Гавриш, О. О. Мельник, Т. А. Роїк, М. Г. Аскеров, О. А. Гавриш : Монографія. - К. : НТУУ «КПІ». 2012. - 196 с.

8. Гавриш А. П. Вплив складу інструменту і режимів тонкого алмазного шліфування на шорсткість поверхонь композитних підшипників ковзання поліграфічних машин / А. П. Гавриш, Т. А. Роїк, П. О. Киричок, О. А. Гавриш, Ю. Ю. Віцюк // Наукові вісті НТУУ «КПІ». - 2013. - № 5. -- С. 71-76.

9. Мельник О. О. Вплив технології виготовлення та магнітно-абразивної обробки на властивості високошвидкісних підшипників / О. О. Мельник, Ю. Ю. Віцюк, А. П. Гавриш, Т. А. Роїк // Вісник Національного технічного університету України «Київський політехнічний інститут». - Серія машинобудування. - К. : НТУУ «КПІ». - 2010. - № 59. - С. 75-78.

10. Эльбор в машиностроении : Монография / В. С. Лысанов, А. В. Букин, Б. А. Глаговский, З. И. Кремень. Под ред. В. С. Лысанова. Ленинград : Машиностроение. - 1978. - 280 с.

11. Гавриш А. П. Алмазно-абразивна обробка магнітних матеріалів / А. П. Гавриш, П. П. Мельничук : Монографія. - Житомир : ЖДТУ, 2003. - 652 с.

12. Гавриш А. П. Вплив абразивного інструменту на шорсткість поверхонь композитних підшипників поліграфічної техніки при тонкому шліфуванні / А. П. Гавриш, П. О. Киричок, Т. А. Роїк, Ю. Ю. Віцюк // Технологія і техніка друкарства. - 2012. - № 3. - С. 65-77.

13. Гавриш А. П. Вплив складу інструменту і режимів тонкого ельборового шліфування на шорсткість поверхонь композитних підшипників ковзання поліграфічних машин / А. П. Гавриш, Т. А. Роїк, П. О. Киричок, О. А. Гавриш, Ю. Ю. Віцюк // Вісник Жит. ДТУ. - 2013. - № 3. - C. $112-120$.

14. Роик Т. А. Обеспечение качества поверхностей деталей из магнитомягких сплавов прецизионной доводкой / Т. А. Роик, П. А. Киричок, А. П. Гавриш, М. Г. Аскеров, Ю. Ю. Вицюк : Монография. - К. : НТУУ «КПІ», 2013. $-233 \mathrm{c}$. 
15. Гавриш А. П. Силове поле при тонкому шліфуванні деталей тертя 3 нових композиційних сплавів для друкарської техніки / А. П. Гавриш, П. О. Киричок, Т. А. Роїк, Ю. Ю. Віцюк // Прогресивные технологии и системы машиностроения (Международный сборник научных трудов) Донец. нац. техн. ун-т. - 2013. - № 2(45). - С. 85-90.

16. Гавриш А. П. Дослідження температур при тонкому абразивному шліфуванні деталей з композитів на основі відходів інструментальних сталей / А. П. Гавриш, П. О. Киричок, Т. А. Роїк, Ю. Ю. Віцюк // Вісник Тернопільського національного технічного університету. - 2013. № 1(69). - C. 125-130.

17. Резников А. Н. Теплофизика резания / А. Н. Резников. - М. : Машиностроение, 1969. - 288 с.

18. Гавриш А. П. Дослідження взаємодії робочих елементів з поверхнею оброблення / А. П. Гавриш // Зб. «Вісник технологічного університету Поділля». - Хмельницький. - 2002. - № 4. - С. 110-120.

19. Кургузов Ю. И. Технологическое обеспечение качества поверхности / Ю. И. Кургузов, Д. Д. Папшев // Вестник машиностроения. - 1986. № 4. - С. 54-56.

20. Дрозд М. С. Инженерные расчеты упругопластической контактной деформации / М. С. Дрозд, М. М. Матлин, Ю. И. Сидякин. - М. : Машиностроение, 1986. - 224 с.

21. Мазель А. Г. Технологические свойства динамического удара / А. Г. Мазель. - М. : Машиностроение, 1969. - 178 с.

22. Одинцов Л. Г. Упрочнение и отделка деталей поверхностным пластическим деформированием / Л. Г. Одинцов. - Справочник. - М. : Машиностроение, 1987. - 328 с.

23. Панасюк В. В. Деякі контактні задачі теорії пружності / В. В. Панасюк, М. І. Теплий. - К. : Наукова думка, 1975. - 195 с.

24. Папшев Д. Д. Отделочно-упрочняющая обработка поверхностным пластическим деформированием / Д. Д. Папшев. - М. : Машиностроение, 1978. - 152 c.

25. Проскуряков Ю. Г. Технология упрочняюще-калибрующей и формообразующей обработки металлов / Ю. Г. Проскуряков. - М. : Машиностроение, 1981. - 208 с.

26. Шуп Т. О. Решение инженерных задач на ЭВМ / Т. О. Шуп. - М. : Мир, 1982. - 242 с.

\section{References}

1. Patent Ukrainy № 102299, MPK S22S33/02. Antyfryktsiinyi kompozytsiinyi material na osnovi instrumentalnoi stali / Roik T. A., Havrysh A. P., Kyrychok P. O., Havrysh O. A., Vitsiuk lu. lu., Melnyk O. O., opubl. 25.06.2013, Biul. № 13.

2. Patent Ukrainy № 41532, MPK S22S33/02. Pidshypnykovyi kompozytsiinyi material / Roik T. A., Havrysh A. P., Havrysh O. A., Vitsiuk lu. lu., Kholiavko V. V., Melnyk O. O., opubl. 25.05.2009, Biul. № 10.

3. Patent Ukrainy № 31545, MPK S22S33/02. Antyfryktsiinyi kompozytsiinyi material na osnovi nikeliu / Roik T. A., Havrysh A. P., Havrysh O. A., Kholiavko V. V., Vitsiuk lu. lu., opubl. 10.04.2008, Biul. № 7.

4. Roik T. A. Kompozytsiini pidshypnykovi materialy dlia pidvyshchennia umov ekspluatatsii / T. A. Roik, P. O. Kyrychok, A. P. Havrysh : Monohrafiia. - K. : NTUU «KPI», 2007. - $404 \mathrm{~s}$.

5. Roik T. A. Suchasni systemy tekhnolohii zahotivelnoho vyrobnytstva $v$ mashynobuduvanni / T. A. Roik, A. P. Havrysh, O. A. Havrysh : Monohrafiia. - K. : EKMO, 2010. - $212 \mathrm{~s}$. 


\section{МАШИНИ I АВТОМАТИЗОВАНІ КОМПЛЕКСИ}

6. Havrysh A. P. Novi tekhnolohii finishnoho obroblennia kompozytsiinykh materialiv $z$ vidkhodiv shvydkorizalnykh stalei na osnovi analizu plivok tertia / A. P. Havrysh, T. A. Roik, P. O. Kyrychok, Iu. lu. Vitsiuk, O. I. Khmiliarchuk, O. O. Melnyk // Naukovi visti NTUU «KPI». - 2011. - № 2. - S. 100-107.

7. Havrysh A. P. Novi tekhnolohii finishnoho obroblennia kompozytsiinykh pidshypnykiv kovzannia dlia zhorstkykh umov ekspluatatsii / A. P. Havrysh, O. O. Melnyk, T. A. Roik, M. H. Askerov, O. A. Havrysh : Monohrafiia. - K. : NTUU «KPI». 2012. - $196 \mathrm{~s}$.

8. Havrysh A. P. Vplyv skladu instrumentu i rezhymiv tonkoho almaznoho shlifuvannia na shorstkist poverkhon kompozytnykh pidshypnykiv kovzannia polihrafichnykh mashyn / A. P. Havrysh, T. A. Roik, P. O. Kyrychok, O. A. Havrysh, lu. lu. Vitsiuk // Naukovi visti NTUU «KPI». - 2013. - № 5. -- S. 71-76.

9. Melnyk O. O. Vplyv tekhnolohii vyhotovlennia ta mahnitno-abrazyvnoi obrobky na vlastyvosti vysokoshvydkisnykh pidshypnykiv / O. O. Melnyk, lu. lu. Vitsiuk, A. P. Havrysh, T. A. Roik // Visnyk Natsionalnoho tekhnichnoho universytetu Ukrainy «Kyivskyi politekhnichnyi instytut». - Seriia mashynobuduvannia. - K. : NTUU «KPI». - 2010. - № 59. - S. 75-78.

10. Jel'bor v mashinostroenii : Monografija / V. S. Lysanov, A. V. Bukin, B. A. Glagovskij, Z. I. Kremen'. Pod red. V. S. Lysanova. - Leningrad : Mashinostroenie. - 1978. - $280 \mathrm{~s}$.

11. Havrysh A. P. Almazno-abrazyvna obrobka mahnitnykh materialiv / A. P. Havrysh, P. P. Melnychuk : Monohrafiia. - Zhytomyr : ZhDTU, 2003. $652 \mathrm{~s}$.

12. Havrysh A. P. Vplyv abrazyvnoho instrumentu na shorstkist poverkhon kompozytnykh pidshypnykiv polihrafichnoi tekhniky pry tonkomu shlifuvanni / A. P. Havrysh, P. O. Kyrychok, T. A. Roik, lu. lu. Vitsiuk // Tekhnolohiia i tekhnika drukarstva. -2012 . - № 3. - S. 65-77.

13. Havrysh A. P. Vplyv skladu instrumentu i rezhymiv tonkoho elborovoho shlifuvannia na shorstkist poverkhon kompozytnykh pidshypnykiv kovzannia polihrafichnykh mashyn / A. P. Havrysh, T. A. Roik, P. O. Kyrychok, O. A. Havrysh, lu. lu. Vitsiuk // Visnyk Zhyt. DTU. - 2013. - № 3. - S. 112-120.

14. Roik T. A. Obespechenie kachestva poverhnostej detalej iz magnitomjagkih splavov precizionnoj dovodkoj / T. A. Roik, P. A. Kirichok, A. P. Gavrish, M. G. Askerov, Ju. Ju. Vicjuk : Monografija. - K. : NTUU «KPI», 2013. $233 \mathrm{~s}$.

15. Havrysh A. P. Sylove pole pry tonkomu shlifuvanni detalei tertia z novykh kompozytsiinykh splaviv dlia drukarskoi tekhniky / A. P. Havrysh, P. O. Kyrychok, T. A. Roik, lu. lu. Vitsiuk // Progresivnye tehnologii i sistemy mashinostroenija (Mezhdunarodnyj sbornik nauchnyh trudov) Donec. nac. tehn. un-t. - 2013. № 2(45). - S. 85-90.

16. Havrysh A. P. Doslidzhennia temperatur pry tonkomu abrazyvnomu shlifuvanni detalei z kompozytiv na osnovi vidkhodiv instrumentalnykh stalei / A. P. Havrysh, P. O. Kyrychok, T. A. Roik, lu. lu. Vitsiuk // Visnyk Ternopilskoho natsionalnoho tekhnichnoho universytetu. - 2013. - № 1(69). - S. 125-130.

17. Reznikov A. N. Teplofizika rezanija / A. N. Reznikov. - M. : Mashinostroenie, 1969. - $288 \mathrm{~s}$.

18. Havrysh A. P. Doslidzhennia vzaiemodii robochykh elementiv z poverkhneiu obroblennia / A. P. Havrysh // Zb. «Visnyk tekhnolohichnoho universytetu Podillia». - Khmelnytskyi. - 2002. - № 4. - S. 110-120.

19. Kurguzov Ju. I. Tehnologicheskoe obespechenie kachestva poverhnosti / Ju. I. Kurguzov, D. D. Papshev // Vestnik mashinostroenija. — 1986. — № 4. S. 54-56. 
20. Drozd M. S. Inzhenernye raschety uprugoplasticheskoj kontaktnoj deformacii / M. S. Drozd, M. M. Matlin, Ju. I. Sidjakin. - M. : Mashinostroenie, 1986. $-224 \mathrm{~s}$.

21. Mazel' A. G. Tehnologicheskie svojstva dinamicheskogo udara / A. G. Mazel'. - M. : Mashinostroenie, 1969. - $178 \mathrm{~s}$.

22. Odincov L. G. Uprochnenie i otdelka detalej poverhnostnym plasticheskim deformirovaniem / L. G. Odincov. - Spravochnik. - M. : Mashinostroenie, 1987. - $328 \mathrm{~s}$.

23. Panasiuk V. V. Deiaki kontaktni zadachi teorii pruzhnosti / V. V. Panasiuk, M. I. Teplyi. - K. : Naukova dumka, 1975. - 195 s.

24. Papshev D. D. Otdelochno-uprochnjajushhaja obrabotka poverhnostnym plasticheskim deformirovaniem / D. D. Papshev. - M. : Mashinostroenie, 1978. - $152 \mathrm{~s}$.

25. Proskurjakov Ju. G. Tehnologija uprochnjajushhe-kalibrujushhej i formoobrazujushhej obrabotki metallov / Ju. G. Proskurjakov. - M. : Mashinostroenie, 1981. - $208 \mathrm{~s}$.

26. Shup T. O. Reshenie inzhenernyh zadach na JeVM / T. O. Shup. - M. : Mir, 1982. - 242 s.

В статье приведены результаты теоретических исследований динамического упрочнения и параметров наклепа в тонких поверхностных слоях композитных деталей трения для печатных машин, изготовленных из новых износостойких композитных материалов на основе отходов инструментальных сталей и обработанных методом тонкого абразивного шлифования.

Ключевые слова: композитные детали, удар, динамическое упрочнение, температурное поле, наклеп, абразивное шлифование.

In the article the theoretical researches of dynamical temperatures influence on the such quality parameters of surfaces like cold-work strengthening in the thin layers composite friction pieces for printing machines, which were manufactured from new wear-resistance composite materials on the base of instrumental steels wastes and finished by fine abrasive grinding methods have been presented.

Keywords: composite pieces, dynamical strength, knock, temperature field, cold-work strengthening, abrasive grinding.

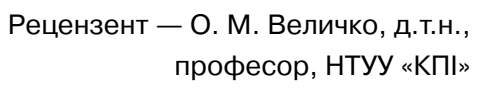
професор, НТУУ «КП।» 